\author{
Agnieszka Rypel \\ Wydział Językoznawstwa Uniwersytetu Kazimierza Wielkiego \\ w Bydgoszczy
}

\title{
Między uniwersytetem a szkołą. Jak przygotować studentów specjalności nauczycielskiej do współczesnego kształcenia językowego
}

Celem artykułu jest nie tyle ukazanie tradycyjnych związków uniwersytetu ze szkołą, polegających na pomnażaniu wiedzy, a następnie przekazywaniu jej w odpowiednio dostosowanej wersji kolejnym pokoleniom uczniów, ile przedstawienie wybranych aspektów roli, jaką uniwersytet odgrywa w przygotowaniu nauczycieli, w tym przypadku polonistów, do wykonywania zawodu w coraz dynamiczniej zmieniającej się rzeczywistości kulturowo-społecznej i komunikacyjno-językowej. Przemiany praktyk językowych wywołane przez wiele zróżnicowanych czynników owocują zmianami w sposobie opisywania języka. Pojawiają się nowe metodologie badawcze, wiele z nich kształtuje się na pograniczu różnych (nie tylko lingwistycznych) dyscyplin. Wpływ tych metodologii daje się zauważyć w najnowszych koncepcjach kształcenia językowego. Można się spodziewać, że po podjęciu pracy w zawodzie szkolnego polonisty dzisiejsi studenci będą musieli zmierzyć się z kolejnymi, coraz szybciej postępującymi przemianami cywilizacyjnymi, które wpłyną na sposób porozumiewania się ich podopiecznych. Nowe kształcenie językowe wytyczy odmienne cele i wykorzysta osiągnięcia dyscyplin i metodologii badających nowe praktyki językowe oraz kontekst, w którym one zachodzą. Rodzi się zatem pytanie, w jaki sposób uniwersytet może, a raczej powinien przygotować przyszłych nauczycieli do umiejętnego reagowania na wyzwania stawiane kształceniu językowemu we współczesnej szkole.

Kształcenie językowe ma swoje korzenie w XVIII-wiecznych reformach Komisji Edukacji Narodowej (KEN, 1773) oraz w działalności Towarzystwa Ksiąg Elementarnych (1775). Obydwie instytucje, powstałe w dogodnym klimacie zmian zachodzących w szkolnictwie zakonnym, miały na celu stworzenie programów nauczania, opracowanie podręczników i zorganizowanie 
powszechnego systemu oświatowego, a przede wszystkim wprowadzenie do szkół języka polskiego. Zgodnie z pragmatycznymi założeniami, którymi przede wszystkim kierowali się twórcy KEN, uczniowie mieli nie tylko poznawać gramatykę języka polskiego, ale również odbierać i tworzyć w tym języku różnorodne teksty, aby w ten sposób przygotowywać się do używania polszczyzny w różnych rolach społecznych, szczególnie w życiu publicznym. Ustawy KEN, pisma Stanisława Konarskiego, Antoniego Popławskiego, Grzegorza Piramowicza, a zwłaszcza Onufrego Kopczyńskiego, którego wkładu w rozwój polskiego językoznawstwa nie sposób przecenić, zawierają wiele cennych uwag stanowiących podwaliny pod to, co dzisiaj nazywamy metodyką ćwiczeń w mówieniu i pisaniu oraz szkolną nauką o języku'.

Wznowienie formalnego nauczania języka polskiego po odzyskaniu niepodległości skutkowało równie bujnym rozkwitem polskiej myśli pedagogicznej i dydaktycznej ${ }^{2}$. Nasi uczeni nie tylko nawiązywali do najnowszych światowych nurtów badawczych, ale też wytyczali kolejne obszary badań i przedstawiali wiele nowatorskich rozwiązań dydaktycznych. To właśnie w dwudziestoleciu międzywojennym w szkolnym nauczaniu wiedzy o języku zaczęto w pełni uwzględniać istniejące od czasów Ferdynanda de Saussure'a rozróżnienie na sferę langue i parole, a więc na system i jego użycie. Wystarczy przywołać tu publikowane w latach 30. prace Jadwigi Dańcewiczowej [1935], dzięki którym do ówczesnych programów nauczania języka polskiego oprócz tradycyjnego opisu systemu językowego wprowadzono aspekty sprawnościowe związane z wykonaniem językowym, a mianowicie mówienie i pisanie oraz działania mające na celu odkrywanie i formułowanie ogólnych prawidłowości, którym język podlega, a następnie analizowanie jego właściwości ujawniających się w poszczególnych użyciach. Współcześnie aspekt sprawnościowy kształcenia językowego, poszerzony o kompetencje odbiorcze, czyli czytanie i słuchanie, odwołuje się do takich dyscyplin pogranicznych, jak socjolingwistyka, etnolingwistyka, psycholingwistyka, a przede wszystkim pragmalingwistyka.

Szeroko rozumiane kształcenie językowe łączące wiedzę o języku z praktycznym rozwijaniem sprawności językowych jest zatem tradycyjnie związane nie tylko z dydaktyką, ale także z lingwistyką. Jak zauważa Jadwiga Kowa-

$1 \mathrm{O}$ związkach nauczania gramatyki w szkołach i rozwoju polskiej lingwistyki obszerniej piszą Michał Jaworski [1991] oraz Danuta Jastrzębska-Golonka [2005].

2 O skali zaangażowania w proces kreatywnego dostosowywania efektów prac europejskich i amerykańskich psychologów, pedagogów i lingwistów do potrzeb szkolnego kształcenia językowego świadczyć może fakt, że owocem dyskusji na ten temat było ok. 199 tys. różnego typu publikacji, które tylko w latach 1930-1939 wyszły spod pióra zarówno dydaktyków, jak i, przede wszystkim, nauczycieli praktyków [zob. Nagajowa 1977: 36]. 
likowa, „[p]omiędzy lingwistyką a dydaktyką językową uważaną słusznie za jedną z dziedzin językoznawstwa stosowanego istnieje naturalna więź"3 [Kowalikowa 2004: 86], która dotyczy przedmiotu poznania - języka. Różnica polega na specyficznym traktowaniu przez dydaktykę samego języka oraz efektów jego poznania, czyli wyników badań językoznawczych, a więc na:

a) przekładaniu podstawowych zagadnień współtworzących przedmiot nauki na komponenty treści nauczania;

b) adaptacji i transformacji teorii naukowych, polegającej na selekcji i określaniu sposobu przedstawienia wybranej problematyki;

c) łączeniu fundamentalnych elementów i wykładników adaptowanej teorii z głównymi, kanonicznymi zasadami efektywnego nauczania;

d) innym niż lingwistyczne podejściu do języka ujawniającym się w sferze celów i interpretacji tych samych zjawisk;

e) traktowaniu mówienia i pisania jako działań oraz dających się rozwijać i doskonalić umiejętności;

f) podporządkowaniu opisu i charakterystyki zjawisk językowych czynnościom ich wykonywania, czyli zachowaniom werbalnym;

g) funkcjonalnym, praktyczno-pragmatycznym ujmowaniu elementów, czynników sprawczych i uwarunkowań uczenia się różnorodnych operacji językowych [Kowalikowa 2004: 86-87].

Dydaktyka języka, nazywana również coraz częściej lingwodydaktyką [por. Rittel 1993; Nocoń 2018], wnosi do szkolnej polonistyki aplikatywny, dostosowany do aktualnych uwarunkowań edukacyjnych wariant wiedzy lingwistycznej - odpowiednio wyselekcjonowanej i synkretycznej, a przy tym

3 Lingwistykę stosowaną łączą z dydaktyką języka te same, praktyczne cele, które można - za Franciszkiem Gruczą - sprowadzić do następujących pytań tematyzujących: a) jakie skutki wywoła się czy spowoduje w komunikacyjnym funkcjonowaniu mówców - słuchaczy, względnie wypowiedzi językowych, jeśli dokona się takiej lub innej zmiany w zakresie posiadanych przez nich właściwości językowych, czyli w zakresie tych ich właściwości, które warunkują ich komunikacyjne funkcjonowanie?; b) jak należy zmienić (przekształcić) właściwości językowe mówców - słuchaczy, względnie wypowiedzi, albo - jak należy wpłynąć na nie, jeśli chce się zmienić funkcjonowanie (zachowanie bądź działanie) komunikacyjne mówców - słuchaczy, względnie wypowiedzi?; c) co i jak należy uczynić, a więc np. jakie właściwości należy nadać tym obiektom lub jakie właściwości muszą one sobie przyswoić (posiąść), jeśli mają być zdolne do spełniania funkcji komunikacyjnych, których jeszcze nie są w stanie spełniać, bądź też do spełniania tych funkcji w warunkach, w których czynić tego dotąd nie potrafiły? [Grucza 1983: 410]. Należy zaznaczyć, że Grucza ani w cytowanej pracy, ani w późniejszym opracowaniu [Grucza 2013] wśród dyscyplin językoznawstwa stosowanego nie wymienia dydaktyki języka ojczystego, choć zalicza do niego glottodydaktykę. 
zaadaptowanej do modelowania działań nauczycieli i uczniów w procesie nabywania sprawności językowych. Eklektyzm wpisany jest w lingwodydaktykę, nie obowiązuje w niej bowiem tak charakterystyczne dla stricte naukowych opisów języka konsekwentne trzymanie się konkretnej metodologii. Wielość i niejednorodność podejść badawczych mogą być owocne w realizacji celów nauczania, ale mogą też przyczyniać się do wielu zakłóceń procesu kształcenia językowego, a nawet do braku jego efektywności. Dla jakości edukacji językowej istotne są zatem odpowiedzi na trzy podstawowe pytania: a) jakie są cele działań dydaktycznych?; b) z jakich opisów języka wybierać, aby cele te zrealizować?; 3) kto ma dokonywać tych wyborów? Innymi słowy - w jaki konkretnie sposób przebiegać powinna transmisja wiedzy z uniwersytetu do szkoły, a może to szkoła reprezentująca potrzeby kolejnych pokoleń użytkowników języka polskiego powinna wpływać na badania uniwersyteckie?

Znakomitym przykładem zrównoważonych relacji między nauką (uniwersytetem) a nauczaniem (szkołą) jest działalność Zenona Klemensiewicza, którego wkład w rozwój językoznawstwa i dydaktyki języka jest doniosły i niepodważalny ${ }^{4}$. Choć w kwietniu 2019 roku minęła pięćdziesiąta rocznica śmierci tego wybitnego badacza, z jego prac ciągle korzystają zarówno studenci polonistyki, ucząc się np. o historii naszego języka, jak i nauczyciele - przecież to głównie Klemensiewiczowi szkolna gramatyka (a zwłaszcza nauczanie składni) zawdzięcza swój tradycyjny kształt, a lekcja nauki o języku - dydaktyczny tok ${ }^{5}$. Jego działalność zawodowa i piśmiennictwo doskonale obrazują funkcjonowanie w dwóch obszarach - uniwersyteckim i szkolnym. W latach 1919-1939 Klemensiewicz był profesorem języka polskiego w Gimnazjum im. Sobieskiego w Krakowie. Jego pierwsze publikacje dotyczyły właśnie nauczania wiedzy o języku. Dzięki postawie refleksyjnego praktyka już po czterech latach został wykładowcą dydaktyki języka polskiego na Uniwersy-

4 Przykładów, kiedy to praca w szkole stawała się impulsem do naukowych dociekań, jest oczywiście znacznie więcej, wystarczy wspomnieć choćby działalność Stanisława Szobera, który od 1903 roku pracował jako nauczyciel w warszawskich szkołach i wykładał w Seminarium Nauczycielskim im. Stanisława Konarskiego. Jednocześnie pracował naukowo i w 1909 roku na uniwersytecie w Moskwie uzyskał tytuł odpowiadający habilitacji. Szober był autorem niezwykle ważnej dla międzywojennej edukacji polonistycznej Gramatyki języka polskiego (jej poszczególne części wydawane w latach 1920-1933 doczekały się aż 22 wznowień), książkę tę opracował też jako podręcznik uniwersytecki, jej całkowicie zmieniona i nieukończona wersja miała być również podręcznikiem akademickim i jednocześnie summą wiedzy o współczesnym języku polskim.

5 Ustalenia Klemensiewicza dotyczące budowy lekcji nauki o języku wykorzystuje Michał Jaworski we wciąż kanonicznej dla adeptów szkolnej polonistyki książce Metodyka nauki o języku polskim [Jaworski 1991: 89-107]. 
tecie Jagiellońskim (a potem w Państwowym Pedagogium w Krakowie oraz w Instytucie Pedagogicznym w Katowicach). Równolegle z doświadczeniami pedagogicznymi rozwijał swoje zainteresowania lingwistyczne i w 1925 roku obronił doktorat z zakresu językoznawstwa, a następnie w 1930 roku uzyskał habilitację z tego samego zakresu. Jednocześnie nadal pracował jako nauczyciel gimnazjalny i w 1933 roku habilitował się z zakresu dydaktyki języka polskiego. Swojej pracy nauczycielskiej nie traktował jedynie jako odskoczni od kariery naukowej - w krakowskim gimnazjum nauczał aż do roku 1939, kiedy to został profesorem tytularnym, a następnie zwyczajnym w Katedrze Języka Polskiego UJ. Działalność na obydwu polach - uniwersyteckim i szkolnym - przerwała dopiero II wojna światowa. Wprawdzie po jej zakończeniu Klemensiewicz skupił się przede wszystkim na badaniach językoznawczych, ale jego związki z edukacją pozostały wciąż żywe [Pisarek 2009]. Warto też zauważyć, że koncepcje dydaktyczne przekazywane przez Klemensiewicza młodym polonistom miały zawsze wymiar formacyjny, o czym świadczy choćby przemówienie wygłoszone w 1967 roku na Uniwersytecie Jagiellońskim podczas spotkania polonistów wykształconych i przygotowanych do pracy nauczycielskiej6.

Istnieje również inny typ związków uniwersytetu ze szkołą, kiedy to praca badawcza naukowców inspiruje ich do sporadycznego, niezwiązanego z głównym nurtem badań, zaangażowania w proces edukacyjny. Dla przykładu, staraniem Komisji Dydaktycznej Rady Języka Polskiego w 2001 roku opublikowano opracowanie zatytułowane Nauka o języku polskim w reformowanej szkole [Mikołajczuk, Puzynina, red. 2001], zawierające propozycję „jednolitego zestawu zagadnień z zakresu wiedzy o języku, które powinny

6 „Dla polonisty język musi być czymś więcej niż dla każdego innego nauczyciela. Jego stosunek do języka musi być inny. A jaki? Idzie o stosunek osobisty do języka ojczystego. Nie tworzy go, choć z pewnością wspiera w sposób bardzo istotny, znajomość gramatyki opisowej i historycznej oraz historii języka, bo nie jest ideałem stosunek naukowo-badawczy, gdzie mowa staje się przedmiotem świadomych obserwacji, dociekań i teoretycznych ujęć, ale właśnie ten żywy, bezpośredni, osobisty, podmiotowy stosunek, gdzie mowa staje się cząstką naszego życia wewnętrznego, wyrazem naszego jestestwa. [...]

Stosunek polonisty do języka musi łączyć postawę rozumową i uczuciową. A wtedy język ojczysty stanie się dla niego wartością godną najwyższego szacunku, miłości i przywiązania, bo będzie widzieć w języku dorobek zarówno wielowiekowego rozwoju ludzkości i narodu, jak też wynik indywidualnego rozwoju jednostki, która nieraz w trudzie i znoju szuka językowej formy dla wewnętrznej treści swego życia. A to znajdzie odbicie we własnej mowie polonisty. Będzie jasna i prosta, rzeczowa i porządna, nie pozbawiona piękna wysłowienia, drgająca bezpośredniością życia w należytej intonacji, we wzorowej dykcji. Ta mowa stanie się najbardziej przekonywającym, najbardziej pociągającym wzorem dla młodzieży" [Klemensiewicz 1982: 778-779]. 
być omawiane na lekcjach języka polskiego - od nauczania początkowego aż do matury" [Markowski 2001: 5]. Dwa lata później ukazało się nowe, rozszerzone i wzbogacone wydanie tej książki pod zmienionym tytułem Wiedza o języku polskim w zreformowanej szkole [Mikołajczuk, Puzynina 2003]. Celem obu wydawnictw było przezwyciężenie chaosu metodologicznego panującego w szkolnej polonistyce po ogłoszeniu pierwszych, bardzo ogólnie sformułowanych podstaw programowych, które zezwalały autorom pisanych $\mathrm{w}$ tym czasie wielu alternatywnych programów nauczania i podręczników na indywidualne interpretowanie treści kształcenia. Wśród badaczy zaangażowanych w tworzenie wymienionych opracowań prezentujących podstawowe pojęcia z zakresu językoznawstwa, ujednolicone metodologicznie, sfunkcjonalizowane i podporządkowane potrzebom praktycznym, znaleźli się m.in. tacy członkowie Komisji Dydaktycznej, jak: Jadwiga Puzynina, Magdalena Danielewiczowa, Jolanta Maćkiewicz, Dorota Zdunkiewicz-Jedynak, Urszula Żydek-Bednarczuk, Jerzy Bartmiński ${ }^{7}$. Wielu z nich było ponadto współautorami koncepcji programowych, np. Tadeusz Zgółka ${ }^{8}$ jako członek zespołu powołanego w latach 90. przez Ministra Edukacji Narodowej w celu opracowania podstawy programowej do nauczania języka polskiego na wszystkich etapach zreformowanej polskiej szkoły lub Jerzy Bartmiński jako współautor tekstocentrycznej koncepcji podstawy programowej dla gimnazjum, która weszła w życie w 2012 roku9 .

Jednak w procesie transpozycji wiedzy uniwersyteckiej na grunt szkolnej polonistyki największe znaczenie ma praca wyspecjalizowanych językoznawców uniwersyteckich, nazywanych również lingwodydaktykami, takich jak przede wszystkim Jadwiga Kowalikowa, Edward Polański, Helena Synowiec, Jerzy Podracki, Bernadeta Niesporek-Szamburska czy Jolanta Nocoń autorów opracowań niezwykle ważnych dla współczesnej dydaktyki języka polskiego. Szczególne znaczenie pracy lingwodydaktyków polega na odna-

7 Do grona autorów należeli ponadto: Jadwiga Kowalikowa, Helena Synowiec, Józef Porayski-Pomsta, Jerzy Podracki, Wilga Herman i Tomasz Karpowicz.

8 Należy zaznaczyć, że Tadeusz Zgółka w latach 2013-2015 uczestniczył w zespole przygotowującym nowy model egzaminu maturalnego (przyczyniając się zwłaszcza do modyfikacji egzaminu ustnego, w którym uwzględniano umiejętności retoryczne zdających). Jest też nie tylko rzeczoznawcą MEN przygotowującym recenzje merytoryczne i językowe podręczników szkolnych, ale również współautorem podręcznika dla szkół ponadgimnazjalnych Mówię, więc jestem. Współautorkami podręczników do nauki o języku i kształcenia językowego są również m. in. Dorota Zdunkiewicz-Jedynak (w serii Słowa i teksty) i Urszula Żydek-Bednarczuk (Wspótczesna polszczyzna i Nasza polszczyzna).

9 Rozporządzenie Ministra Edukacji Narodowej z dnia 27 sierpnia 2012 r. w sprawie podstawy programowej wychowania przedszkolnego oraz kształcenia ogólnego w poszczególnych typach szkół. 
lezieniu balansu między poszczególnymi metodologiami dyscyplin naukowych inspirujących szkolną naukę o języku i naukę języka. Dla kształcenia sprawności porozumiewania się za pośrednictwem rozmaitych wypowiedzi umotywowanych celem komunikacji oraz intencjami jej uczestników czerpią ze strukturalizmu, socjolingwistyki, pragmalingwistyki (teorii aktów mowy) i kognitywizmu, reagując na sprawy wyłaniające się na bieżąco, a aktualnie ważne z punktu widzenia ucznia oraz nabywanych przez niego wiadomości i umiejętności. Jednocześnie nie zaniedbują zagadnień kanonicznych, niejako ponadczasowych, takich jak np. nauczanie ortografii czy kształcenie odmiany pisanej [Kowalikowa 2004: 87]. Jak zauważa Anna Janus-Sitarz,

[d]ydaktyka to bardzo specyficzna dziedzina, która z racji swych zadań musi być ogromnie wyczulona na wszelkie funkcjonujące w innych obszarach wiedzy i życia teorie, tendencje, kierunki. Jej rolą jest przefiltrować je przez sito przydatności, zweryfikować użyteczność i sens wprowadzania na którymś z etapów edukacji. Wobec ogromnego przyrostu wiedzy, zalewu informacji, nadmiaru nowych terminów, trzeba w sposób ostrożny i krytyczny, ale zarazem otwarty i elastyczny, podchodzić do decyzji wykorzystania nowości w praktyce szkolnej. [Janus-Sitarz 2004: 107]

Podsumowując ten wątek rozważań, trzeba zadać pytanie, dlaczego mimo tak, wydawałoby się, ścisłych związków uniwersytetu ze szkołą nieustannie słyszy się narzekania na pogarszający się stan edukacji językowej, a także obniżający się poziom kompetencji komunikacyjnych (w tym językowych, tekstowych i dyskursywnych) kolejnych pokoleń uczniów, a zatem też studentów.

Dyskusje toczące się w środowiskach uniwersyteckich (i to nie tylko w kręgu dydaktyków języka) nad rolą nauki o systemie językowym oraz o związkach pomiędzy wiedzą o języku a jego poprawnymi i sprawnymi użyciami toczyły się już w pierwszej połowie XX wieku. Wystarczy tu wspomnieć choćby o polemice zwolenników przekonań Jana Baudouina de Courtenay, Stanisława Szobera i Henryka Gaertnera - według których tradycyjne nauczanie gramatyki nie wspiera umiejętności władania językiem, a niekiedy wręcz ją upośledza - z wyrazicielami poglądów Zenona Klemensiewicza i Witolda Doroszewskiego, uznających, że teoria wspiera praktykę, a poznanie pomaga w działaniu, dlatego dobra znajomość gramatyki wpływa na jakość operacji językowych ${ }^{10}$. Polemiki te wprawdzie przycichły i w szkole zatriumfowało strukturalistyczno-normatywne podejście do nauczania o języku, ale już od

10 Więcej o tej dyskusji - zob. Kowalikowa 2004: 106-108. 
lat 90. ubiegłego wieku ponownie toczą się spory o kształt koncepcji scalającej obszar edukacji polonistycznej nazywany kształceniem językowym ${ }^{11}$. W szkolnej polonistyce, dopuszczającej w owym czasie wielość rozwiązań programowych, pojawiły się zarówno spekulacyjne konstrukty, jak np. propozycje Kordiana Bakuły, który całkowicie odrzucał nauczanie gramatyki, a podstaw teoretycznych umożliwiających mentalizację komunikacyjnego doświadczenia uczniów poszukiwał przede wszystkim w teorii aktów mowy oraz retoryce rozumianej jako lingwistyka tekstu [zob. Bakuła 1994, 1995, 1997), jak i praktyczne rozwiązania, takie jak oparta na teorii aktów mowy koncepcja krakowskiego zespołu To lubię!, która znalazła ukonkretnienie w programach nauczania i serii podręczników, wykorzystujących funkcjonalne i komunikacyjne podejście do kształcenia językowego ${ }^{12}$. W miarę upływu czasu koncepcji tych przybywało i być może właśnie w ich wielości i różnorodności, ale także częstotliwości zmian zachodzących pod ich wpływem w kolejnych podstawach programowych należy doszukiwać się jednej z przyczyn słabości edukacji polonistycznej.

Jolanta Nocoń w książce Lingwodydaktyka na progu XXI wieku. Konteksty - koncepcje - dylematy (2018) podjęła się próby uporządkowania tych koncepcji (nazywanych w niniejszym artykule podejściami ${ }^{13}$ ), które od 1990 roku pojawiały się w kolejnych dokumentach programowych. Badaczka wyróżniła następujące podejścia: podmiotowe, komunikacyjne, funkcjonalne i tekstocentryczne.

Podejście podmiotowe ma swoje źródło we współczesnych koncepcjach filozoficznych (filozofii dialogu, filozofii spotkania) i pedagogicznych (zwłaszcza w tzw. pedagogice humanistycznej w różnych jej wariantach,

11 Świadectwo tych polemik odnaleźć można na łamach „Polonistyki” z lat 1994-1996. Najbardziej interesujące i ważne dla współczesnej dydaktyki języka teksty opublikowane w tym piśmie zamieszczone zostały w zredagowanych przez Bożenę Chrząstowską zbiorach Kompetencje szkolnego polonisty (1995, 1997).

12 Wykładnia metodologiczna i dydaktyczna koncepcji To lubię została przedstawiona w: Dyduch, Jędrychowska, Kłakówna, Mrazek, Steczko 1994 oraz Jędrychowska, Kłakówna, Mrazek, Steczko 1996.

13 Na gruncie dydaktyki ogólnej koncepcją programową określa się teorię doboru treści kształcenia. Na gruncie dydaktyki szczegółowej termin podejście ma w stosunku do terminu koncepcja węższy zakres i dotyczy konkretnych założeń oraz inspiracji metodologicznych służących do realizowania wybranych koncepcji dydaktycznych i programowych. Choć można dość precyzyjnie określić wyznaczniki podejścia, nie znaczy to, że można je utożsamiać z jedną wybraną metodą lub jednym typem podręcznika. Podejście stanowi zatem rodzaj ramy porządkującej różnorodne zagadnienia, które mogą pojawiać się także niezależnie od innych rozwiązań dydaktycznych [Rypel 2007: 15]. 
takich jak np. pedagogika postaci, osoby, istnienia czy wartości). Wpłynęły one na ukształtowanie się antropocentryzmu dydaktycznego [por. Rypel 2007: 38-48], który w odniesieniu do kształcenia językowego pozwala na przyjęcie założenia, że „każdy uczeń jest określoną osobowością i trzeba mu pomóc w tworzeniu i rozumieniu udanych (fortunnych) wypowiedzi. Nie jest to abstrakcyjny, idealny znawca języka polskiego, lecz żywa jednostka ludzka, która rosnąc zmienia się i coraz więcej potrafi i umie" [Wiśniewska 1999: 350]. Upodmiotowienie procesu kształcenia językowego stało się możliwe dzięki teoriom lingwistycznym o wyraźnym antropocentrycznym nastawieniu. Takie dyscypliny językoznawcze, jak etnolingwistyka, psycholingwistyka, socjologia i teoria aktów mowy, wyraźnie akcentują osobę mówiącą, jej zachowania oraz ich konteksty. Podejście podmiotowe zasadza się zatem na prymarnej opozycji: przedmiot kształcenia (treści kształcenia wywodzące się z dorobku dyscypliny macierzystej - językoznawstwa) - podmiot kształcenia (uczeń, nauczyciel). Celem nauczania nie jest wyłącznie transfer wiedzy - sformalizowanej i odtwórczej (wówczas, jak to ujmuje Maria Dudzik, „,szkoła staje się skarlałym uniwersytetem"), ale są nim pomaganie uczniowi w doświadczaniu własnego rozwoju oraz wychowanie w autentyczności językowej i odpowiedzialnym użyciu słowa [Dudzik 1999: 363]. Nastawienie na tego, kto mówi, a więc na wykonanie, jest ważniejsze niż systemowa wiedza o języku, bo to ono dowodzi opanowania kompetencji komunikacyjnej [Wiśniewska 1999: 356].

Językowi przypisana zostaje podwójna rola: filtru, przez który człowiek (uczeń, nauczyciel) poznaje świat, oraz narzędzia projekcji i konstruowania świata [Kowalikowa 2004: 124]. W tym ujęciu język traktowany jest jako sposób rozumienia rzeczywistości przez daną społeczność językową - ,interpretator i interpretant zawierający najistotniejsze treści kultury" [Anusiewicz 1995: 10]. W związku z tym w podejściu podmiotowym w centrum nauczania stawia się formy i struktury językowe naznaczone semantycznie, a więc leksykę, frazeologię, metaforykę oraz stereotypy językowe, językowy i tekstowy obraz świata (środki językowe, za pomocą których ten świat jest kreowany), a także wartościowanie za pomocą języka [Karwatowska 1998: 146]. W procesie nauczania-uczenia bierze się również pod uwagę przeobrażenia dokonujące się we współczesnej kulturze, stanowiącej najszerzej pojmowane środowisko wychowawcze młodego pokolenia [Polakowski 1998: 16].

Podejście komunikacyjne ma swoją genezę w glottodydaktyce [zob. Stawna 1991]. Zakłada, że podstawowym składnikiem koncepcji nauczania języka jest taka teoria, która przyjmuje jego określoną, kognitywną naturę, co w pierwszej kolejności umożliwia badania nad jego przyswajaniem i uczeniem się. Dopiero na tej podstawie możliwe jest sformułowanie teorii uczenia 
się języka, w tym języka obcego [Martyniuk 1999: 42]. Wychodząc z tego założenia, glottodydaktycy wypracowali koncepcję nauczania języka, u której podstaw leży, wspólne funkcjonalizmowi, psycholingwistyce i socjolingwistyce, przekonanie, że porozumiewanie się polega nie na układaniu zdań, ale na używaniu języka po to, aby realizować pożądane cele i zaspokajać różnorodne potrzeby jego użytkowników. Podejście komunikacyjne odrzuca, właściwe lingwistyce strukturalnej (łącznie z gramatyką transformacyjno-generatywną), zainteresowanie idealnie biegłym mówiącym - słuchaczem, umiejscowionym w społeczności doskonale jednorodnej. W zamian za to przyjmuje, że w każdym społeczeństwie funkcjonuje więcej niż jeden system mówienia i każdy z systemów ma własne reguły, wartości i własne dokonania. W tradycyjnych programach tok nauczania zdeterminowany jest przez system i struktury języka, a podstawową jednostką nauczania jest zdanie. W podejściu komunikacyjnym punktem wyjścia są akty mowy, a za podstawową jednostkę nauczania uznaje się dyskurs, rozumiany jako tekst stanowiący treściowo i formalnie określoną całość realizującą wybraną funkcję językową [Rypel 2007: 31], ta zaś definiowana jest jako cel, dla którego mówiący używa języka w porozumiewaniu się z ludźmi, np. kiedy coś twierdzi, wyraża prośbę, przyrzeka czy opisuje [por. Komorowska 1976]. Tym samym znacznemu osłabieniu ulega pozycja tradycyjnych obszarów kształcenia językowego (w tym wiedzy o języku). Są one podporządkowane komunikacyjnie sprofilowanej pragmatyce, semantyce, retoryce i lingwistyce tekstu [Bakuła 1997: 183]. Miejsce systematycznego kursu zorientowanej strukturalnie gramatyki zajmuje jej okazjonalne nauczanie w duchu sfunkcjonalizowania na poziomie tekstu [Dyduch i in. 1994: 27].

Podejście komunikacyjne zakłada możliwość modyfikacji programu nauczania uwzględniającą każdą zmianę w społecznych praktykach komunikacyjnych [Bakuła 1997: 183] i dowartościowuje aspekt społeczny komunikowania się, uwzględniając różne warianty interakcji, zróżnicowane role komunikacyjne oraz intencjonalność aktów mowy [Dyduch i in. 1994: 18]; kształci określone zachowania językowe osadzone w kontekstach językowych, czyli przyjmuje strategię uczenia się drogą wykonań językowych w połączeniu z nauczaniem sytuacyjnym [Nocoń 2018: 64; Rypel 2007: 55-59].

Podejście funkcjonalne - $\mathrm{w}$ dydaktyce idea funkcjonalności stanowi zaprzeczenie szkodliwej utopii encyklopedyzmu, zgodnie z którą nauczanie „wszystkich wszystkiego" i zapamiętywanie jak największej liczby informacji jest nadrzędnym celem uczenia się [Rypel 2007: 49]. Jak wskazuje praktyka edukacyjna, nawet najlepiej uporządkowana wiedza nie może służyć usprawnieniu ludzkiego działania, jeśli nie stanowi podstawy do nabywania umiejętności. Aby wiedza była operacyjna, a nie wyłącznie faktograficzna, musi 
być zdobywana w działaniu, które wymaga wykorzystania szeregu sprawności. W kontekście edukacji językowej problematyka związku między wiedzą a umiejętnościami przekłada się na związek nauki o języku (a ściślej gramatyki) z kształceniem kompetencji nadawczo-odbiorczych. Wielu dydaktyków uniwersyteckich już na przełomie XX i XXI wieku zdecydowanie opowiadało się za „odgramatycznieniem” gramatyki [Patrzałek 1992], nauką o języku dla nauki języka [Nagajowa 1994] i „upotrzebnieniem” gramatyki [Kowalikowa 2004]. Postulowali, aby miejsce nauczania tradycyjnej sformalizowanej i abstrakcyjnej gramatyki opisowej zajęło kształtowanie świadomości językowej ${ }^{14}$ ucznia, tj. „takiej wiedzy o języku, która zyskałaby wymiar narzędzia przydatnego do percypowania świata i twórczego w nim funkcjonowania" [Nocoń 2018: 72].

Zamiast na analizie paradygmatów podejście funkcjonalne koncentruje się na wydobywaniu funkcji tworzących je elementów, czyni to jednak nie w obrębie systemu (czyli względem siebie), ale w kontekście szeroko rozumianych procesów mówienia, słuchania, czytania i pisania [Kowalikowa 2004: 116]. Sfunkcjonalizowaną wiedzę o języku wiąże z umiejętnościami nadawczo-odbiorczymi i możliwościami tworzenia różnorodnych tekstów w różnych układach komunikacyjnych [Żydek-Bednarczuk 2009: 59]. Uwzględnia ponadto rolę form gramatycznych w szerszym kontekście wypowiedzi- łączy zjawiska fleksyjne, słowotwórcze i składniowe z intencją danego gatunku i stylu, skupiając się przede wszystkim na tych zagadnieniach językowych, które są potrzebne w procesie komunikacji.

Najpełniejszą wykładnię funkcjonalnego nauczania wiedzy o języku znaleźć można w pracach Jadwigi Kowalikowej i Heleny Synowiec [2005]. Obie badaczki za fundamentalny i elementarny poziom budowania rozmaitych sprawności językowych uznają funkcjonalność wewnątrzjęzykową (pozwalającą dzięki analizie funkcji elementów języka w obrębie systemu na poznawanie właściwości i możliwości języka jako tworzywa tekstu). W dalszej kolejności wyodrębniają funkcjonalności: tekstową (na tym poziomie analizy bada się funkcje języka w konkretnych użyciach ${ }^{15}$ ), integracyjną (traktującą język

14 Dyskusje nad sposobem rozumienia świadomości językowej - zob. Nocoń, Tabisz, red. 2014.

15 Badaczki wyróżniają dwa typy funkcjonalności tekstowej. W typie pierwszym przedmiotem operacji poznawczych są teksty lub ich fragmenty wyrwane z naturalnego, życiowego kontekstu komunikacyjnego - służą wprowadzeniu jakiegoś konkretnego zagadnienia, a nie rozwijaniu autentycznej sprawności komunikacyjnej. W typie drugim przedmiotem operacji poznawczych są ukontekstowione teksty lub ich fragmenty - uczeń wchodzi w pewnym sensie do środka aktu komunikacyjnego jako nadawca/odbiorca [Nocoń 2018: 71]. 
jako klucz do interpretacji każdego tekstu, także literackiego [por. Kowalikowa 2007]), kreatywną (wskazującą na twórczy, autorski wymiar wszystkich działań językowych [por. Kowalikowa 2012]), pragmatyczną (służącą realizacji różnych form wypowiedzi), retoryczną (uwzględniającą aspekt estetyczny i etyczny użycia języka w tekstach oraz perswazyjność i oddziaływanie wypowiedzi w procesie komunikacyjnym), kognitywną (odnoszącą się do języka jako filtru poznawczego) oraz komunikacyjną (obejmującą wszystkie pozostałe wymiary) [por. Nocoń 2019: 74].

Podejście tekstocentryczne wychodzi z założenia, że ,człowiek żyje w uniwersum tekstów - ciągle je odbiera, nieustannie tworzy: mówione, pisane, ikoniczne, ikoniczno-werbalne, o różnych funkcjach, w różnych stylach i w najróżniejszych sytuacjach" [Nocoń 2018: 88], dlatego dziecko, ucząc się mowy, przyswaja nie tylko system językowy, ale także równolegle wzorce zachowań językowych - skonwencjonalizowane modele tekstów. Tekst jest komunikacyjną całością, a nie jedynie wytworem aktu mowy, wielozdaniową strukturą, poddającą się autonomicznemu opisowi na poziomie języka, dlatego rolę edukacji językowej pojmuje jako badanie języka w tekście i dla tekstu. Szkolna, abstrakcyjna (bo oderwana od tekstu) nauka o języku jest zbędna, bowiem gramatyka, retoryka, gatunek i informacje są zawarte właśnie w tekście. Tekst tworzony i odbierany przez ucznia traktuje się zatem jako kategorię porządkującą treści i działania edukacyjne. Uważa się go za narzędzie rozwijania i doskonalenia kompetencji komunikacyjnej (w tym tekstotwórczej) i źródło świadomości językowej, a miarą efektywności procesu dydaktycznego staje się umiejętność zastosowania wiedzy o języku do recepcji i tworzenia tekstu. W edukacji polonistycznej podejście to znalazło konkretne odzwierciedlenie w podstawie programowej z 2008 roku, w której znaleźć można liczne inspiracje tekstologią lingwistyczną [por. Bartmiński, Niebrzegowska-Bartmińska 2009].

Przedstawione tu pobieżnie koncepcje kształcenia językowego w ciągu niemal 30 lat, a więc od czasu opublikowania pierwszej podstawy programowej, odcisnęły swoje piętno na kolejnych podstawach i programach nauczania oraz częściowo na podręcznikach. Czy jednak odcisnęły je na szkolnej praktyce edukacyjnej?

Analizując dokumenty programowe oraz piśmiennictwo dydaktyczne, Jadwiga Kowalikowa doszła do wniosku, że ,współczesne kształcenie językowe jest naznaczone z jednej strony kontynuacją, a z drugiej zmianą. Łączy w sobie tradycję z innowacją. Wydaje się, że więcej w nim modyfikowanego trwania niż bezpowrotnego przemijania" [Kowalikowa 2004: 95], jednak odnosząc się do szkolnej codzienności, trudno oprzeć się wrażeniu, że edukacji języ- 
kowej bliżej do spetryfikowanego trwania niż modyfikowania, a w przypadku szkolnictwa średniego można nawet mówić o jej degradacji. Kolejne podstawy programowe, kolejne koncepcje nauczania stają się swoistymi fasadami, za którymi nadal króluje tradycyjne podejście systemowo-normatywne. W praktyce nie przyjęła się ani komunikacyjno-funkcjonalna koncepcja To lubię!, ani tekstologiczne podejście podstawy programowej z 2008 roku, ani też funkcjonalne nauczanie wiedzy o języku i właściwe integrowanie jej z kształceniem literackim zalecane również we wcześniejszych dokumentach. Tendencje do utrzymania tego dotąd nieoficjalnego, wygodnego dla nauczycieli, autorów zadań egzaminacyjnych i konkursowych status quo do pewnego stopnia sankcjonuje obecnie obowiązująca podstawa programowa - pozbawiona spójnej koncepcji, odtwarzająca (poza nielicznymi wyjątkami) dawne strukturalistyczne schematy wiedzy o języku. Można przypuszczać, że nawet zamieszczenie w niej zagadnień związanych z retoryką dalej pozostanie pustym zapisem, tak jak to było w przypadku podstawy programowej z 1999 roku, w której retorykę włączono w zakres kształcenia językowego na poziomie szkoły średniej.

W jakiej mierze za ten stan rzeczy mogą odpowiadać uniwersytety? Oczywisty jest fakt, że to właśnie uczelniom wyższym szkolni poloniści zawdzięczają zdobycie kompetencji merytorycznych, a ściślej wiedzy lingwistycznej jako nieodzownego ich składnika. Skończenie studiów polonistycznych nie stanowi jednak gwarancji, że wszyscy nauczyciele będą sobie radzić z całą problematyką, jaką przewidują kolejne podstawy programowe. Z przedstawionego wcześniej przeglądu podejść do kształcenia językowego wynika, że w pracach lingwodydaktyków i autorów dokumentów programowych znaleźć można nawiązania do: językoznawstwa kognitywnego, lingwistyki kulturowej, pragmalingwistyki, socjolingwistyki, socjologii języka, psycholingwistyki, lingwistyki kulturowej, etnolingwistyki, semantyki, tekstologii oraz różnych teorii komunikacji i teorii dyskursu, a co najważniejsze - żadne z podejść nie odwołuje się do jednej wybranej dyscypliny i metodologii. Nauczyciel korzystający z podstawy programowej może mieć trudności z tym, aby wyodrębnić i odpowiednio zastosować w planowaniu zajęć kryteria przyjęte w łączeniu metodologii różnych dyscyplin językoznawczych, co więcej, może nie znać lub nawet nie wiedzieć o istnieniu teorii językoznawczych, do których odwołują się autorzy kolejnych dokumentów programowych.

Powody takiej sytuacji mogą być różne. Najbardziej trywialnym wyjaśnieniem braków rzeczowych w warsztacie szkolnych polonistów mogą być trudności, jakie przedmioty językoznawcze sprawiają wielu studentom filologii polskiej. W ich przypadku prześlizgnięcie się przez egzaminacyjne sito nie oznacza gruntownej wiedzy, ponadto wiadomości powierzchowne, nie- 
utrwalone, rzadko odświeżane szybciej uciekają z pamięci. Często jeszcze przed skończeniem studiów w wiedzy lingwistycznej przyszłych nauczycieli powstają (i/lub utrwalają się) takie ubytki, że, jak to ujmuje Kowalikowa, polonista rozpoczynający pracę w szkole potrzebuje ,językoznawczej reedukacji” [Kowalikowa 2006: 293], która na początku drogi zawodowej nie jest zadaniem łatwym. W rezultacie czujący się niepewnie w problematyce lingwistycznej nauczyciel nie potrafi zinterpretować zapisów podstawy programowej, czego konsekwencją jest wycofanie się z ich realizowania i wybór łatwiejszej, bo utrwalonej i obrosłej wieloma opracowaniami metodycznymi drogi nauczania normatywno-systemowego. Takie wyjaśnienie byłoby jednak zbyt proste problemy z interpretacją oraz wcielaniem $\mathrm{w}$ życie zapisów podstawy programowej mają również studenci zainteresowani przedmiotami językoznawczymi, a także doświadczeni nauczyciele, którzy rozpoczynali pracę w szkole, ,wiedząc o języku wszystko, co zaoferowały im studia polonistyczne" [Kowalikowa 2006: 293]. Nie czują się oni jednak zbyt pewnie we współczesnej problematyce lingwistycznej. Dla wszystkich nauczycieli - niezależnie od stażu zawodowego - problematyczne jest także rozejście się współczesnej teorii naukowej z tradycją dydaktyczną, np. w zakresie nauczania składni czy klasyfikacji części mowy.

Wynika z tego, że odpowiedzialność uczelni za przygotowanie studentów do zawodu nauczyciela języka polskiego nie może ograniczać się jedynie do prowadzenia zajęć z metodyki nauczania tego przedmiotu szkolnego - dotyczą one przecież w równym stopniu kształcenia językowego, jak również literackiego i kulturowego, a ponadto mają inne zadania i cele, do których z pewnością nie należy przygotowanie merytoryczne z zakresu poszczególnych dyscyplin naukowych. Konieczne jest zatem przemodelowanie dydaktyki uniwersyteckiej w sposób, który przygotuje szkolnych polonistów do samodzielnej interpretacji zjawisk językowych i odnoszenia do nich różnorodnych metodologicznie opisów. Oznacza to, że dydaktyka uczelni wyższej pilnie wymaga sfunkcjonalizowania. Nie wystarczy już tradycyjne i ciągle najważniejsze w kształceniu akademickim podejście polegające na wykształceniu studenta - znawcy języka i opisujących go metodologii. Zdobywaniu wiedzy teoretycznej powinno, jak się zdaje, towarzyszyć zdobywanie wiedzy funkcjonalnej, użytkowej, spraktycyzowanej i refleksyjnej, przede wszystkim pojęciowej, a nie wyłącznie terminologicznej. W akademickiej dydaktyce przedmiotów lingwistycznych należałoby przyjąć strategie nauczania uwzględniające stawianie studenta w różnych, lecz komplementarnych rolach:

a) obserwatora języka, wstępnie rozpoznającego właściwości przykładowego materiału językowego, który następnie poddawany jest ukie- 
runkowanej analizie, badaniu, ocenie, i na tej podstawie budującego wiedzę metajęzykową i metakomunikacyjną;

b) analityka konstrukcji językowych zarówno oderwanych od kontekstu użycia, jak i będących konkretyzacjami abstrakcyjnego systemu;

c) badacza języka samodzielnie formułującego problem poznawczy, stawiającego hipotezy, weryfikującego je i opracowującego wnioski;

d) wykonawcy działań językowo-komunikacyjnych będących tekstową konkretyzacją struktur i reguł wewnątrzjęzykowych i prowadzących do uświadomienia sobie sposobów działania języka w aktach komunikacji werbalnej;

e) krytyka języka w użyciu posługującego się wiedzą normatywną (gramatyczną, ortograficzną i interpunkcyjną) i oceniającego odpowiedniość stylistyczną środków językowych tekstów cudzych i własnych ${ }^{16}$.

Dzięki wykorzystaniu takich strategii uczenia się student może być znacznie lepiej przygotowany do „pomnażania i aktualizowania własnej wiedzy lingwistycznej, niezbędnej do swobodnego poruszania się w obrębie problematyki językowej i operowania nią w różnych kontekstach, układach i sytuacjach dydaktycznych" [Kowalikowa 2006: 281]. Samokształcenie jest wpisane w zawód nauczyciela - praca szkolnego polonisty obliguje do śledzenia na bieżąco wszystkiego, co dzieje się w językoznawstwie. Jeśli ma się on stać prawdziwym specjalistą, winien poznawać, przyswajać i pośrednio wykorzystywać (choćby w roli kontekstów) najnowsze poglądy i aktualne wyniki badań, a podjęcie pracy w szkole nie może dla niego oznaczać całkowitego odcięcia się od polonistyki uniwersyteckiej [Kowalikowa 2006: 293].

Taka postawa, choć pożądana, nie jest jednak powszechna. Spośród wielu różnych przyczyn nauczycielskich zaniechan, jedną z ważniejszych wydaje się brak umiejętności samodzielnego analizowania zjawisk językowych i wykorzystywania w tym celu aktualnej literatury przedmiotu, która te zjawiska pozwala oświetlić z innej strony. Zadaniem dydaktyki uniwersyteckiej (nie tylko zresztą przedmiotów językoznawczych) byłoby zatem kształcenie postaw badawczych, dzięki którym szkolny polonista nie tylko będzie mógł, ale przede wszystkim będzie chciał śledzić najnowsze teorie, kierunki badań i tendencje współczesnej lingwistyki, a następnie w sposób ostrożny i krytyczny, ale zarazem otwarty i elastyczny podchodzić do decyzji wykorzystywania nowości w praktyce edukacyjnej. Łatwiej będzie mu wówczas ocenić i następnie

16 Zaproponowana tu klasyfikacja ról zainspirowana jest wyodrębnionymi przez Jolantę Nocoń strategiami uczenia (się) sfunkcjonalizowanej wiedzy o języku [Nocoń 2018: 81-88]. 
wdrożyć uwzględniające najnowszy stan propozycje lingwodydaktyków oraz zapisy kolejnych podstaw programowych.

Kolejnym wyzwaniem stojącym przed dydaktyką akademicką są przemiany we współczesnej komunikacji społecznej, za których sprawą powstają nowe wzory zachowań językowo-komunikacyjnych. Badania prowadzone w środowiskach uniwersyteckich opisują te wzorce i uogólniają wnioski płynące z obserwacji najnowszych tendencji, ale nie można zapominać, że studenci podlegają tym samym, badanym przez naukowców procesom, co przekłada się na ich możliwości poznawcze i kompetencje językowe. Na uczelnie wkroczyło pokolenie cyfrowych tubylców. Na przemiany ich stylu komunikowania się oddziałuje szereg czynników kulturowo-cywilizacyjnych, spośród których, zdaniem Jacka Warchali, za najistotniejsze uznać należy, po pierwsze: ekspansję nowego sposobu percepcji świata, który postrzegany jest przede wszystkim jako doświadczenie wizualne, i po drugie: gwałtowne rozprzestrzenianie się nowego stylu życia oddziałującego na zachowania językowe, co przejawia się przede wszystkim powszechną akceptacją dla potoczności w sposobie myślenia oraz konstruowania wypowiedzi (zwłaszcza pisemnych) [Warchala 2013: 184]. W jakim stopniu dydaktyka uniwersytecka powinna reagować na te zmiany czy ma być hybrydyczna, otwarta, dynamiczna i uwzględniać zapotrzebowania społeczeństwa informacyjnego, akceptować i współtworzyć nowe oraz przeobrażać stare kompetencje komunikacyjne i językowe, czy też zamknąć się na nie, ignorując fakt bardzo gwałtownych i głębokich przemian zachodzących w stylu myślenia nowych pokoleń.

Z tym wiąże się także kwestia otwarcia dydaktyki akademickiej na metody nauczania wykorzystujące nowe technologie - nowe przynajmniej dla niektórych wykładowców akademickich, bo z pewnością nie dla studentów, aczkolwiek i oni stale bombardowani są różnymi technologicznymi nowinkami. Choć teraz dobrze radzą sobie z ich oswajaniem, w pewnym momencie kariery zawodowej mogą również pozostać w tyle za swoimi uczniami, dlatego także oni powinni poznawać sposoby wykorzystywania nowych technologii - niezależnie od tego, w jakim kierunku będą zmierzać zachodzące w nich zmiany.

W opracowanym przez Rubena Puentedurga modelu wprowadzania nowoczesnych technologii (SAMR) w obszar dydaktyki wyodrębnione zostały następujące etapy tego procesu:

a) zastąpienie - nowe metody używane do rozwiązywania starych zadań (np. zamiast na papierze - na komputerze, zamiast na tablicy - na tablicy multimedialnej);

b) rozszerzenie - włączanie narzędzi mających wzbudzić zainteresowanie uczących się (np. różnego rodzaju aplikacji interaktywnych); 
c) modyfikacja - technologie informacyjno-komunikacyjne niezbędne do wykonania zadania (np. nagranie telefonem komórkowym konkretnej realizacji językowej w jej naturalnym kontekście komunikacyjnym jako materiału do analizy zachowań językowych ${ }^{17}$ );

d) redefinicja-rozszerzenie puli zadań o takie aktywności, które pozwalają na samodzielne tworzenie materiałów egzemplifikacyjnych, tworzenie grup zadaniowych itp. [Kulig-Kozłowska 2017: 61-62].

Z przedstawionego zestawienia wynika, że rzeczywiste podnoszenie jakości procesu nauczania-uczenia się wymaga zarówno od obecnych, jak i od przyszłych wykładowców, studentów i nauczycieli takiego korzystania z nowych technologii, aby nie stanowily one kolejnej fasady, tym razem pseudonowoczesności. Nowe technologie nie mogą być na uczelniach i w szkołach jedynie niewiele znaczącym sztafażem. Ich właściwe wykorzystywanie świadczy bowiem o tym, że dydaktyka (zarówno uniwersytecka, jak i szkolna) dostosowuje się do aktualnego stanu procesów poznawczych, strategii komunikacyjnych i kompetencji językowych uczniów i studentów, a tym samym może na te procesy, strategie i kompetencje wpływać.

Przedstawione $\mathrm{w}$ artykule uwagi nie wyczerpują problematyki sygnalizowanej w tytule. Stanowią raczej przyczynek do poważnej dyskusji nad przemianami w dydaktyce uniwersyteckiej. Międzypokoleniowa transmisja wiedzy, a także przekazywanie pożądanego kształtu języka stają się we współczesnej szkole obszarem swoistego konfliktu interesów między pokoleniem zstępującym a pokoleniem wchodzącym do szkół. Konfliktu tego nie da się rozstrzygnąć jedynie przez włączanie nowych treści do tych, które w programach nauczania zakorzenione są często od stulecia (tak jak np. pewne dzieła literackie w kanonie lektur szkolnych czy tradycyjna gramatyka opisowa). $\mathrm{Z}$ niektórych elementów trzeba zrezygnować, a w ich miejsce wprowadzić nowe, co często pociąga za sobą przewartościowanie sposobu organizowania, przekazywania i funkcjonalizowania wiedzy. Brak przyzwolenia na rezygnowanie z pewnych obszarów wiedzy i nieumiejętność wypracowania koncepcji jej selekcjonowania sprawiają, że edukacja szkolna staje się powoli anachroniczna [Rypel 2017: 211]. Chodzi o to, aby edukacja akademicka nie podzieliła tego samego losu.

17 Tego typu działania mogą mieć również charakter formacyjny, służą uwrażliwieniu na etyczny aspekt nagrywania osób, które nie zdają sobie sprawy z faktu, że ich wizerunek, słowa, zachowania są rejestrowane bez ich wiedzy i przyzwolenia. 


\section{Bibliografia}

Anusiewicz Janusz (1995), Lingwistyka kulturowa. Zarys problematyki, Wydawnictwo Uniwersytetu Wrocławskiego, Wrocław.

Bakuła Kordian (1994), Szkolna nauke o języku trzeba zmienić, „Polonistyka” 1994, nr 5, s. 274-281.

Bakuła Kordian (1995), Przeciw gramatyce, przeciw martwej tradycji..., „Polonistyka", nr 4, s. 207-212.

Bakuła Kordian (1997), Kształcenie językowe w szkole podstawowej w świetle wspótczesnych teorii psychologicznych i lingwistycznych: projekt nowej metodyki, Wydawnictwo Uniwersytetu Wrocławskiego, Wrocław.

Bartmiński Jerzy, Niebrzegowska-Bartmińska Stanisława (2009), Tekstologia, Wydawnictwo Naukowe PWN, Warszawa.

Chrząstowska Bożena, red. (1995), Kompetencje szkolnego polonisty, Wydawnictwa Szkolne i Pedagogiczne, Warszawa.

Chrząstowska Bożena, red. (1997), Kompetencje szkolnego polonisty 2, Wydawnictwa Szkolne i Pedagogiczne Warszawa.

Dańcewiczowa Jadwiga (1935), Dydaktyka mówienia i pisania jako działu nauczania języka ojczystego, w: Encyklopedia wychowania, t. 2, red. Stanisław Łempicki i in., Wydawnictwo Naszej Księgarni Związku Nauczycielstwa Polskiego, Warszawa.

Dudzik Maria (1999), Człowiek w edukacji polonistycznej, w: Z uczniem pośrodku. Podmiotowa dydaktyka literatury, języka, kultury, red. Zofia Budrewicz, Maria Jędrychowska, Wydawnictwo Naukowe Akademii Pedagogicznej, Kraków, 362-367 .

Dyduch Barbara, Jędrychowska Maria, Kłakówna Zofia Agnieszka, Mrazek Halina, Steczko Iwona (1994), ,, To lubię!’. Możliwe - konieczne - pożyteczne. Podręcznik do języka polskiego dla klasy czwartej. Książka nauczyciela, Wydawnictwo Edukacyjne, Warszawa-Kraków.

Gajda Stanisław (1992), Co się dzieje we współczesnym językoznawstwie, „Polonistyka”, nr 3, s. 138-144.

Gajda Stanisław (1996), Trudne upotrzebnienie, „Polonistyka”, nr 6, s. 240-241.

Grucza Franciszek (1983), Zagadnienia metalingwistyki. Lingwistyka-jej przedmiot, lingwistyka stosowana, Państwowe Wydawnictwo Naukowe, Warszawa.

Grucza Franciszek (2013), Lingwistyka stosowana. Historia-zadania-osiagnięcia, Wydawnictwo Naukowe Instytutu Kulturologii i Lingwistyki Antropocentrycznej Uniwersytetu Warszawskiego, Warszawa.

Horwath Ewa (2014), Teorie językoznawcze w szkolnej dydaktyce, w: Szkolna polonistyka zanurzona w języku, red. Anna Janus-Sitarz, Ewa Nowak, Universitas, Kraków, s. 63-86. 
Janus-Sitarz Anna (2004), „, Nie ma rozpusty większej niz myślenie...”. Teksty filozoficzne w edukacji polonistycznej, w: Przygotowanie ucznia do odbioru różnych tekstów kultury, red. Anna Janus-Sitarz, Universitas, Kraków, s. 91-110.

Jastrzębska-Golonka Danuta (2005), Ewolucja wiedzy fonetycznej w opracowaniach i podręcznikach dla szkót średnich okresu międzywojennego (na tle historii nauczania języka polskiego), Wydawnictwo Uniwersytetu Kazimierza Wielkiego, Bydgoszcz.

Jaworski Michał (1991), Metodyka nauki o języku polskim, Wydawnictwa Szkolne i Pedagogiczne, Warszawa.

Jędrychowska Maria, Kłakówna Zofia Agnieszka, Mrazek Halina, Steczko Iwona (1996), ,, To lubię!’. Program nauczania języka polskiego w klasach IV-VIII, Wydawnictwo Edukacyjne, Warszawa-Kraków.

Karwatowska Małgorzata (1998), Kiedy językoznawcy używaja terminu antropocentryzm? (przegląd literatury), w: Podmiotowy wymiar szkolnej polonistyki, red. Zenon Uryga, Wydawnictwo Naukowe Wyższej Szkoły Pedagogicznej, Kraków, s. 141-147.

Klemensiewicz Zenon (1982) Składnia, stylistyka, pedagogika językowa, red. Anna Kałkowska, Państwowe Wydawnictwo Naukowe, Warszawa.

Komorowska Hanna (1976), Kompetencja komunikatywna a zagadnienie ksztatcenia językowego, ,Języki Obce w Szkole”, nr 1, s. 22-29.

Kowalikowa Jadwiga (2004), Ksztatcenie językowe. Teoria dla praktyki, w: Polonista w szkole. Podstawy ksztatcenia nauczyciela polonisty, red. Anna Janus-Sitarz, Universitas, Kraków, s. 85-138.

Kowalikowa Jadwiga (2006), Narodziny nauczyciela polonisty, Universitas, Kraków. Kowalikowa Jadwiga (2007), Od języka do literatury - od literatury do języka, w: Szkolne spotkania z literatura, red. Anna Janus-Sitarz, Universitas, Kraków, s. 129-159.

Kowalikowa Jadwiga (2012), Wspieranie kreatywności uczniów przez rozwijanie ich sprawności językowych, w: Twórczość i tworzenie w edukacji polonistycznej, red. Anna Janus-Sitarz, Universitas, Kraków, s. 143-158.

Kowalikowa Jadwiga, Synowiec Helena (2005), Miejsce nauki o języku w kształceniu językowym uczniów, w: Szkolna polonistyka zanurzona w języku, red. Anna Janus-Sitarz, Ewa Nowak, Universitas, Kraków.

Kulig-Kozłowska Agnieszka (2017), Facebook w szkolnej ławce. Media społecznościowe a edukacja polonistyczna, Universitas, Kraków.

Martyniuk Waldemar (1999), Poststrukturalistyczny model uczenia się i nauczania języka obcego/drugiego, „Nowa Polszczyzna”, nr 1, s. 39-50.

Mikołajczuk Agnieszka, Puzynina Jadwiga, red. (2001), Nauka o języku polskim w reformowanej szkole, Wydawnictwo Nowa Era, Warszawa. 
Mikołajczuk Agnieszka, Puzynina Jadwiga, red. (2003), Wiedza o języku polskim w zreformowanej szkole, Nowa Era, Warszawa.

Nagajowa Maria (1977), Ćwiczenia w mówieniu i pisaniu, Wydawnictwa Szkolne i Pedagogiczne, Warszawa.

Nocoń Jolanta (2018), Lingwodydaktyka na progu XX wieku. Konteksty - koncepcjedylematy, Wydawnictwo Uniwersytetu Opolskiego, Opole.

Nocoń Jolanta, Tabisz Anna, red. (2014), Świadomość językowa, Wydawnictwo Uniwersytetu Opolskiego, Opole (Język a Edukacja, t. 3).

Pisarek Walery (2009), Zenon Klemensiewicz - w czterdziestolecie śmierci, „LingVaria”, nr 2, s. 179-199.

Polakowski Jan (1998), Idee dydaktyki podmiotowej w podstawowych problemach kształcenia literackiego (nurt antropocentryczno-kulturowy), w: Podmiotowy wymiar szkolnej polonistyki, red. Zenon Uryga, Wydawnictwo Naukowe Wyższej Szkoły Pedagogicznej, Kraków.

Rittel Teodozja (1993), Podstawy lingwistyki edukacyjnej. Nabywanie i ksztatcenie języka, Wydawnictwo Naukowe Wyższej Szkoły Pedagogicznej, Kraków.

Rypel Agnieszka (2007), Nauczanie komunikacyjne w kształceniu uczniowskich wypowiedzi pisemnych. Problemy. Badania eksperymentalne. Implikacje dydaktyczne, Wydawnictwo Uniwersytetu Kazimierza Wielkiego, Bydgoszcz.

Rypel Agnieszka (2017), Przyszłość polszczyzny w edukacji - spotkanie w pót drogi, w: Przyszłość polszczyzny - polszczyzna przyszłości, red. Katarzyna Kłosińska, Rafał Zimny, Narodowe Centrum Kultury, Warszawa, s. 211-212.

Stawna Mirosława (1991), Podejście komunikacyjne do nauczania języków obcych. Od teorii do praktyki, Wydawnictwa Szkolne i Pedagogiczne, Warszawa.

Warchala Jacek (2013), Uwagi o wspótczesnej piśmienności, „Konteksty Kultury”, nr 10, s. 182-192.

Wiśniewska Halina (1999), Antropocentryzm a ksztatcenie językowe, w: Z uczniem pośrodku. Podmiotowa dydaktyka literatury, języka, kultury, Wydawnictwo Akademii Pedagogicznej, Kraków, s. 348-361.

Żydek-Bednarczuk Urszula (2009), Nowe aspekty kompetencji komunikacyjnej, w: W trosce o dobrą edukację, red. Anna Janus-Sitarz, Universitas, Kraków, s. 51-62.

\section{Agnieszka Rypel \\ Between school and university. How to prepare teaching specialization students for modern language education}

The purpose of this article is to show the role of the university in the transfer of knowledge and to prepare future teachers to transfer this knowledge at school. This is an 
extremely important problem due to contemporary cultural and social changes causing very dynamic language changes. The methods used to describe the language are changing as well. The language education model is already anachronistic in Polish schools because it doesn't respond to this evolutionm which is why universities must prepare future teachers to react to changes on their own.

KEYWORDS: knowledge transmission; contemporary models of language; education; university tasks.

dr hab. Agnieszka Rypel, prof. UKW - Wydział Językoznawstwa, Uniwersytet Kazimierza Wielkiego w Bydgoszczy; zainteresowania badawcze: nowe koncepcje kształcenia językowego, a zwłaszcza tworzenia wypowiedzi pisemnych, ustalenia metodologiczne dotyczące dyskursu edukacyjnego oraz stosowane w nim mechanizmy perswazyjne, wychowanie językowe, a także językowy i kulturowy obraz miasta. 
